\title{
An investigation on flotation process of low-grade Niobium/Tantalum ore
}

\author{
Willie Nheta, Brian Ruwizhi \\ University of Johannesburg \\ P.O. Box 17011, Doornfontein 2028, Johannesburg, South Africa \\ wnheta@uj.ac.za; brianruwizhi@gmail.com
}

\begin{abstract}
In this paper, the characterization and flotation performance of AM810 Hydroxamic acid on Niobium (Nb) and Tantalum (Ta) ore was investigated. The ore was characterized using X-ray fluorescence (XRF) and X-ray diffraction (XRD). Flotation experiments were carried out in a 3 litre Leeds Barker laboratory flotation cell. It was observed that the ore was a low grade Nb-Ta ore constituting $0.01 \% \mathrm{Nb}$ and $0.04 \% \mathrm{Ta}$ interlocked in $32.42 \% \mathrm{Si}$ matrix together with other gangue minerals such as $\mathrm{Al}$, $\mathrm{Na}$, $\mathrm{K}$, Fe and $\mathrm{Ca}$ minerals. Major mineral phases bearing $\mathrm{Nb}$ and $\mathrm{Ta}$ were Ilmenorutile $\left[\mathrm{FeO}\left(\mathrm{Nb}_{2} \mathrm{Ta}_{2} \mathrm{O}_{5} .5 \mathrm{TiO} \mathrm{O}_{2}\right]\right.$, Pyrochlore $\left[(\mathrm{Na}, \mathrm{Ca}, \mathrm{Ce})_{2}(\mathrm{Nb}, \mathrm{Ta})_{2} \mathrm{O}_{6}(\mathrm{OH}, \mathrm{F})\right]$ and Tapiolite $\left[(\mathrm{Fe}, \mathrm{Mn})(\mathrm{Nb}, \mathrm{Ta})_{2} \mathrm{O}_{6}\right]$. Milling tests conducted at varying times show that the ore was fairly hard producing $80 \%$ passing $150 \mu \mathrm{m}$ after milling for 40 minutes in a laboratory rod mill. Flotation tests indicated that at a grind of $80 \%$ passing $75 \mu \mathrm{m}$ and collector dosage of $2000 \mathrm{~g} / \mathrm{t}$ (AM810 Hydroxamic acid), a flotation concentrate assaying $0.10 \% \mathrm{Nb}$ and $0.13 \%$ at a recovery of 77.02 and $82.74 \%$ respectively was obtained.
\end{abstract}

Keywords: Niobium, Tantalum, Coltan, Flotation, Pyrochlore,

\section{Introduction}

Froth flotation process has proved to be superior over other concentration methods when treating pyrochlore $\left((\mathrm{Na}, \mathrm{Ca})_{2} \mathrm{Nb}_{2} \mathrm{O}_{6}(\mathrm{OH}, \mathrm{F})\right.$ ores. This has led to use of reverse gangue flotation prior to pyrochlore flotation in cases were the ore contains high content of carbonate minerals [1]. Fatty acids are used as primary collectors. In cases where the ore does not contain carbonate minerals, direct pyrochlore flotation is applied using cationic amine collectors at acidic $\mathrm{pH}$. A typical example is the flotation process applied at Araxa mine in Brazil [1]. However, there is need for continuous investigation on suitable reagents for flotation of ores containing both $\mathrm{Nb}$ and Ta minerals [2].

In the Democratic Republic of Congo (DRC), owing to the strong social and political conflicts, columbite-tantalite mining and extraction is largely done at artisanal and small-scale level. Thus, metallurgical processes of beneficiating $\mathrm{Nb} / \mathrm{Ta}$ ores are not well developed [3]. This has led to the lack of appropriate investigations on their mineralogical occurrences and characteristics, information which is key when choosing the appropriate concentration and beneficiation routes to maximise on recovery. The challenge of depleting high-grade ores coupled with new ore bodies having complex mineralogy and recording lower mineral grades has raised the need for alternative beneficiation methods. Gravity concentration is the main method used to concentrate $\mathrm{Nb} / \mathrm{Ta}$ minerals in $\mathrm{DRC}$, however it performs poorly in low grade ores. [4].

The beneficiation of $\mathrm{Nb} / \mathrm{Ta}$ ores usually involves preconcentration, primary concentration and secondary concentration. The choice to use one or all these processes would depend on the nature of the ore, particularly the content of Ta in the ore relative to its associated minerals and impurities. Typically, mechanically mined ores contain less than $0.1 \% \mathrm{Ta}$, and would therefore essentially require enrichment through the three processes stated above [4].

Flotation of $\mathrm{Nb} / \mathrm{Ta}$ ore depends on the ratio of $\mathrm{Ta}$ to $\mathrm{Nb}$ in the ore and the nature of the gangue minerals and their composition in the ore. Oxide mineral flotation is often affected by the type, nature and complexity of the ore itself. It is also affected by the type and nature of other minerals present in the ore and the type and nature of the gangue minerals in the deposit such as slimes and clays [5]. Thus, froth flotation of $\mathrm{Nb} / \mathrm{Ta}$ minerals is largely dependent on the source and characterization of the ore. The Kibara belt has a high $\mathrm{Ta} / \mathrm{Nb}$ ratio [2].

Hydroxamic acids have widely reported as effective collectors in flotation tests for a wide variety of oxide minerals such as cassiterite, copper, iron and tungsten, but there have been few notable studies on its application on $\mathrm{Nb} / \mathrm{Ta}$ ores [6]. Previous studies have shown that Hydroxamic acids have the most ideal collecting power in the neutral to slightly alkaline 
pulps (pH 6-9). The advantage they have shown over other collectors is that their dependence on $\mathrm{pH}$ is not as much as the other collectors based on their electrostatic interaction. However, the high consumption of Hydroxamic acids as collectors has been a significant cost factor in the flotation of fines, as well as an environmental issue [6,7].

In the present work, an alkyl hydroxamate was used as a potential collector of $\mathrm{Nb} / \mathrm{Ta}$ minerals using direct flotation with the objective of recovering $\mathrm{Nb} / \mathrm{Ta}$ minerals from low grade ores.

\section{Materials and Method}

\subsection{Materials}

Coltan ore sample used in the present studies was obtained from the Kibara Belt located in Katanga Province in the DRC. Its X-ray fluorescence (XRF) and X-ray diffraction (XRD) results are shown in Table 1 and Figure 1. Table 1 shows that the grade of $\mathrm{Nb}$ and $\mathrm{Ta}$ was $0.01 \%$ and $0.04 \%$ respectively indicating that it's a low-grade $\mathrm{Nb}$-Ta ore. Figure 1 shows that the major mineral phases bearing $\mathrm{Nb}$ and $\mathrm{Ta}$ were Ilmenorutile $\left[\mathrm{FeO}\left(\mathrm{Nb}, \mathrm{Ta}_{2} \mathrm{O}_{5} .5 \mathrm{TiO}_{2}\right]\right.$, Pyrochlore $\left[(\mathrm{Na}, \mathrm{Ca}, \mathrm{Ce})_{2}(\mathrm{Nb}, \mathrm{Ta})_{2} \mathrm{O}_{6}(\mathrm{OH}, \mathrm{F})\right]$ and Tapiolite $\left[(\mathrm{Fe}, \mathrm{Mn})(\mathrm{Nb}, \mathrm{Ta})_{2} \mathrm{O}_{6}\right]$. The main gangue bearing minerals in the sample were Quartz $\left(\mathrm{SiO}_{2}\right)$ and Albite $\left(\mathrm{NaAlSi}_{3} \mathrm{O}_{8}\right)$. The sample was milled to $80 \%$ passing 75 microns and used as the flotation feed. AM810 Hydroxamic acid supplied by Axis House, South Africa was used as the collector while a 99.5\% pure Hydrated Oxalic acid $\left(\mathrm{H}_{2} \mathrm{C}_{2} \mathrm{O}_{4} * 2 \mathrm{H}_{2} \mathrm{O}\right)$ with molar mass of $126.07 \mathrm{~g} / \mathrm{mol}$ was used as the depressant.

Table 1: Chemical Composition of the head sample

\begin{tabular}{|l|l|l|l|l|l|l|l|l|}
\hline ELEMENT & $\mathrm{Si}$ & $\mathrm{Al}$ & $\mathrm{K}$ & $\mathrm{Na}$ & $\mathrm{Fe}$ & $\mathrm{Ca}$ & $\mathrm{Nb}$ & $\mathrm{Ta}$ \\
\hline \% wt & 32.42 & 10.18 & 3.15 & 3.09 & 0.84 & 0.66 & 0.01 & 0.04 \\
\hline
\end{tabular}

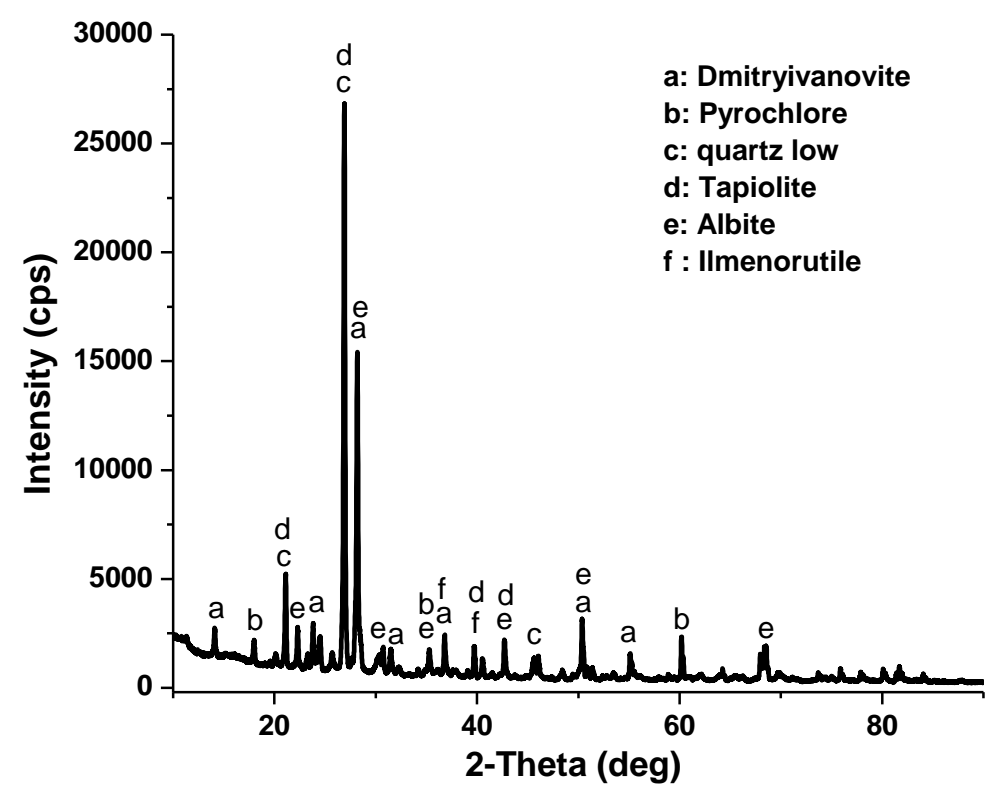

Fig.1. XRD pattern of the coltan sample. 


\subsection{Milling Experiments}

$500 \mathrm{~g}$ of the ore sample was used for the milling tests to come up with a grind calibration curve which would help to control the P80 grind to be obtained. The $500 \mathrm{~g}$ ore sample was dry milled in a laboratory size rod mill using 12 steel rods for $10 \mathrm{~min}$ followed by screen analysis. The milling procedure was repeated for 20, 30 and 40min using the same ore sample and screen analysis performed after each time interval. A P80 $(\mu \mathrm{m})$ vs Grind time graph was then plotted to obtain the grind calibration curve. The time needed to mill under the same conditions to obtain the target grind of $80 \%$ passing $75 \mu \mathrm{m}$ were deduced from the curve.

\subsection{Flotation Experiments}

The flotation experiments were carried out in a 3 litre Leeds Barker laboratory type flotation cell. The impeller speed of the flotation machine was kept constant at $1200 \mathrm{rpm}$ for both conditioning and flotation process. Running tap water at natural $\mathrm{pH}$ of 7 was added first along with $500 \mathrm{~g}$ of ore feed to obtain a pulp of about $20 \%$ solids and conditioned for 5 minutes. The depressant for the gangue minerals, Oxalic acid $(500 \mathrm{~g} / \mathrm{t})$ was added to the pulp and conditioned for 5 minutes. AM810 Hydroxamic acid as a collector was added to the system and further conditioned for 5 minutes. A pH of 7 was maintained for the flotation tests. Downfroth 250 used as the frother was added followed by 3 minutes mixing period. Air at an air-flow rate of $7 \mathrm{~L} / \mathrm{min}$ was introduced into the cell and the froth products were collected for 5 minutes. The froth was scraped into the concentrate collection dishes every 15 seconds. The float (concentrate) and non-float (gangue) products were filtered, dried, weighed and analysed for $\mathrm{Nb}$ and $\mathrm{Ta}$. The recovery of $\mathrm{Nb}$ and $\mathrm{Ta}$ were then calculated using equation 1.

Where

$$
\% \text { Recovery }=(C c *(\mathrm{~F}-\mathrm{T}) / \mathrm{Fc} *(\mathrm{~F})) * 100
$$

Cc: Concentrate grade: F - Feed mass; T - Tailings mass and Fc - concentration of feed.

\section{Results and Discussion}

\subsection{Milling Experiments}

Milling experiments were performed on the coltan ore and the results are shown in Figure 2. From Figure 2, it can be seen that $80 \%$ passing $150 \mu \mathrm{m}$ can be obtained after milling for 40 minutes.

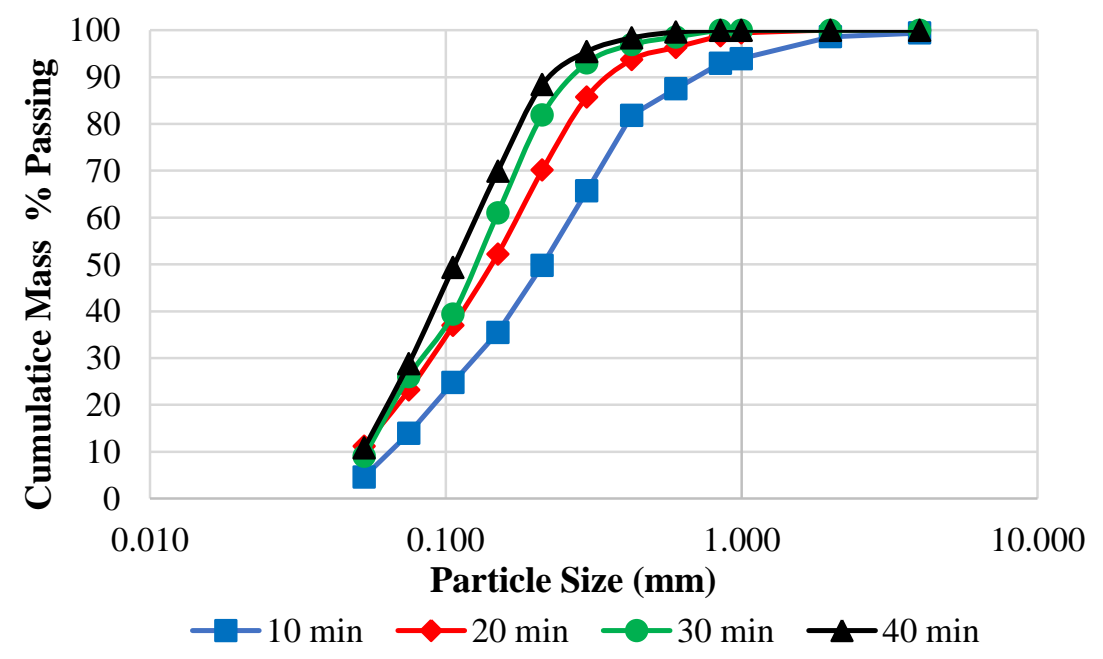

Fig 2: Particle size distribution of the milled samples (10, 20, 30 and $40 \mathrm{~min})$ 
The P80 was then plotted vs time to determine the time required to mill the sample and produce $80 \%$ passing 75 $\mu \mathrm{m}$ and the results are shown in Figure 3. Figure 3 illustrates that the sample needed to be milled for 170mins in a rod mill. This milling time was used to prepare all samples for the flotation experiments.

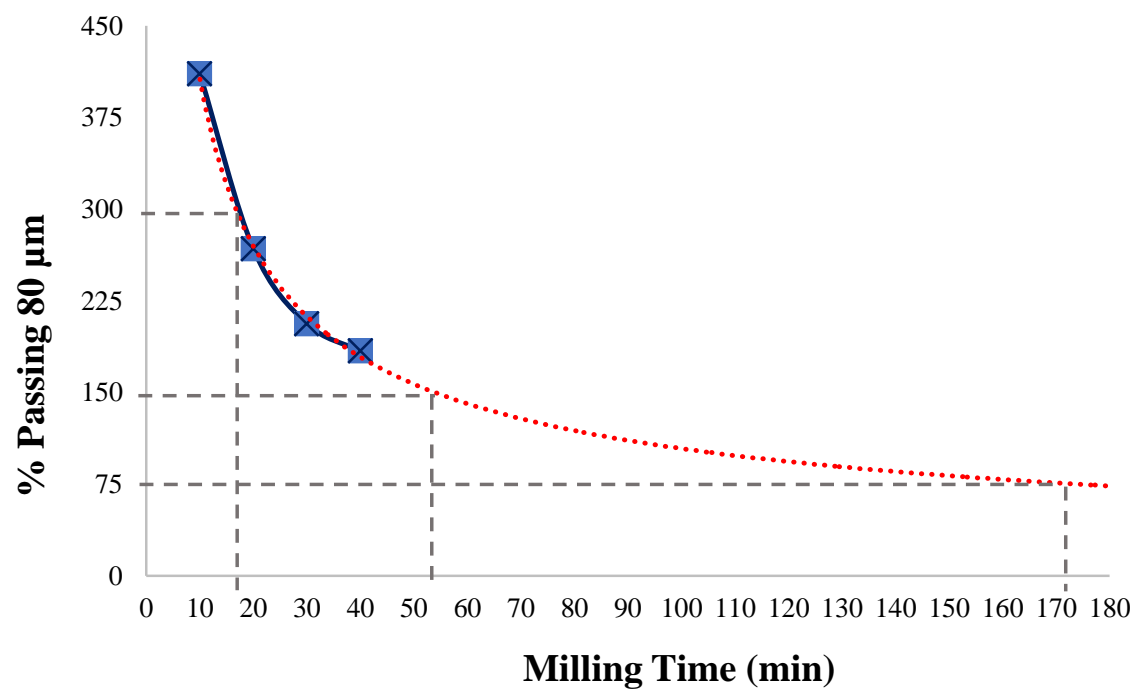

Fig. 3: Milling curve of milling Coltan sample in a rod mill.

\subsection{Flotation Experiments}

Flotation tests were conducted to determine the effect of particle size and the effect of collector dosage for the flotation of low grade Coltan ore. The results obtained for all flotation tests conducted were evaluated on three parameters which include $\mathrm{Nb}$-Ta grade, $\mathrm{Nb}$-Ta recovery and $\mathrm{Si}$ recovery, these being discussed on the basis that the $\mathrm{Nb}$-Ta concentrate was the froth phase collected over the flotation cell lip and the Si tails being the pulp remaining in the flotation cell after the duration of the flotation tests.

\subsubsection{Effect of Particle Size}

Flotation tests were conducted to examine the effect of particle size for flotation of $\mathrm{Nb}$-Ta and to determine the optimum particle size fraction for the recovery and upgrade of $\mathrm{Nb}$-Ta. The flotation experiments were carried out for the size fractions of $80 \%-300 \mu \mathrm{m}, 80 \%-150 \mu \mathrm{m}$ and $80 \%-75 \mu \mathrm{m}$. The results for the cumulative recovery for the $\mathrm{Nb}, \mathrm{Ta}$ and $\mathrm{Si}$ against the varying particle sizes are illustrated on Figure 4.

The highest total $\mathrm{Nb}$-Ta recovery of the concentrate was achieved on the flotation of the $80 \%-75 \mu \mathrm{m}$ size sample with recoveries of $\mathrm{Nb}$ and $\mathrm{Ta}$ being $74.61 \%$ and $74.80 \%$ respectively. Recoveries of $\mathrm{Nb}$ and $\mathrm{Ta}$ decreased with increase in size. This was expected as the courser the particle the more work of adhesion is required and the lower the recoveries. However, particle size distribution did not affect much the distribution of Si reporting to the concentrate for the different particle sizes $(39.90 \%, 42.39 \%$ and $42.31 \%)$. Hence a strong depressant for $\mathrm{Si}$ is required [1]. The grades of grades of $0.06 \% \mathrm{Nb}$ and $0.13 \%$ Ta were achieved at when floating ore with particle size distribution of $80 \%$ passing $75 \% \mu \mathrm{m}$. 


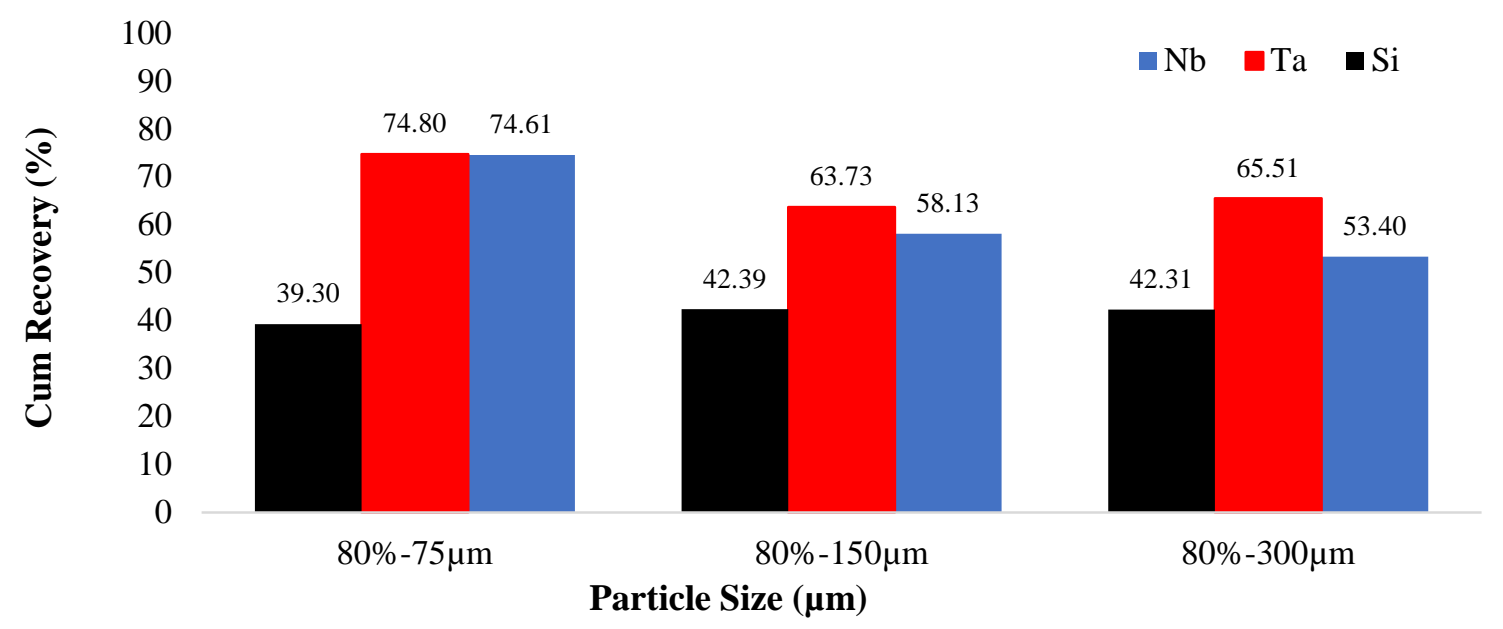

Fig. 4: Effect of particle size on the recovery of $\mathrm{Nb}$, Ta and $\mathrm{Si}$

\subsubsection{Effect of Collector Dosage}

Flotation tests were conducted to examine the effect of collector dosage on flotation of Nb-Ta minerals and the results are shown in Figure 5. Figure 5 shows that the recovery of $\mathrm{Nb}$ and $\mathrm{Ta}$ increases with increase in collector dosage with a highest recovery $\mathrm{Nb}$ and $\mathrm{Ta}$ at 77.02 and $82.74 \%$ respectively. However, collector dosage had no much effect on the recovery of $\mathrm{Si}$ with a slight increase of $5.3 \%$ as collector dosage increase from 1000 to $2000 \mathrm{~g} / \mathrm{t}$.

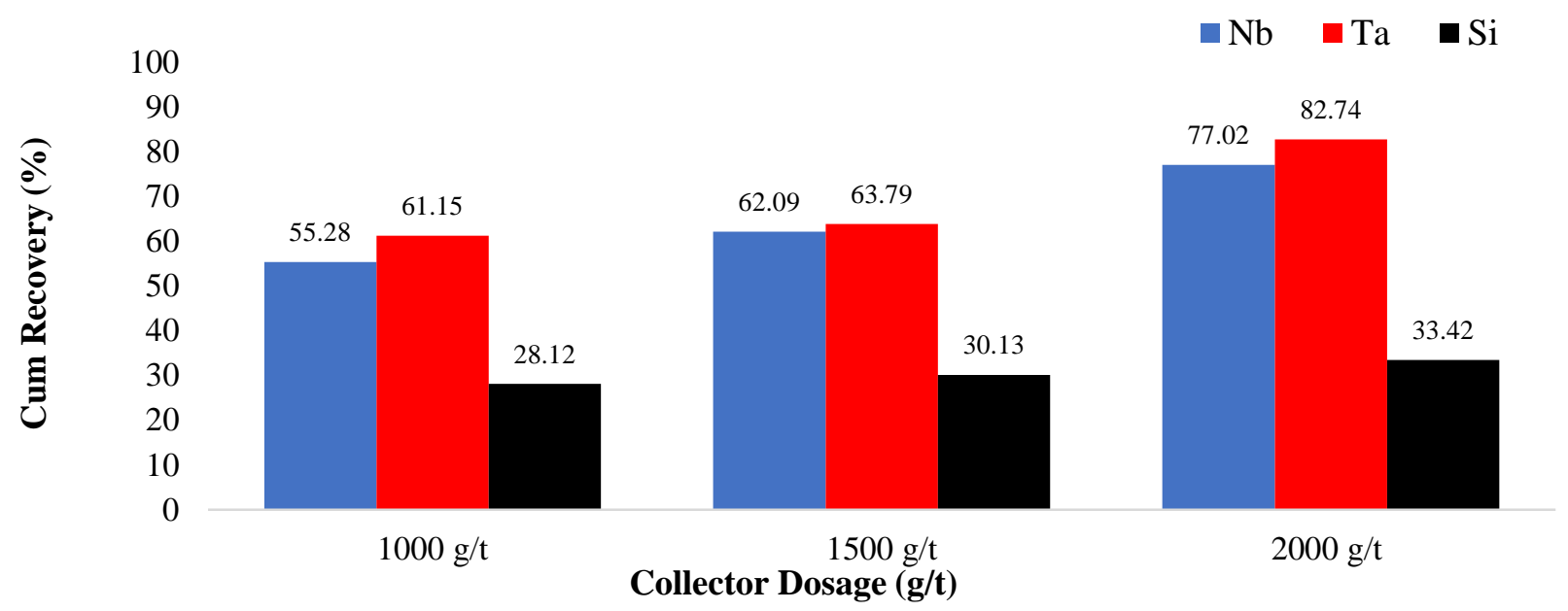

Fig 5: Effect of collector dosage on Nb-Ta recovery

The effect of the collector dosage on the grade of the concentrate was investigated and the results are shown in Figure 6. Here, it is evident that with increased addition of collector, significantly improves flotation of both $\mathrm{Nb}$ and $\mathrm{Ta}$ minerals. The highest grades where recorded for $2000 \mathrm{~g} / \mathrm{t}$ dosage with grades of $0.10 \%$ and $0.13 \%$ achieved for $\mathrm{Nb}$ and $\mathrm{Ta}$ respectively. 

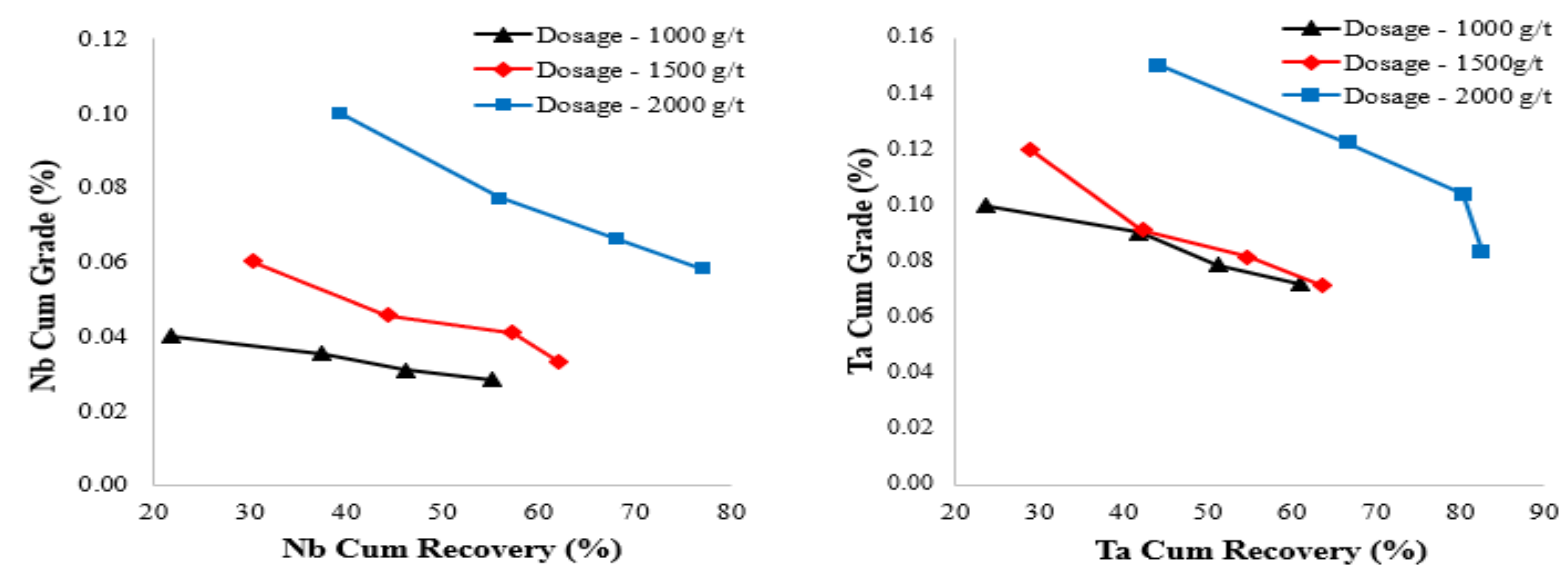

Fig. 6: Grade-recovery curve for $\mathrm{Nb}$ and Ta flotation at various collector dosage.

\section{Conclusion}

In this paper, the characterisation and flotation performances of AM810 hydroxamic acid on Coltan ore from the Kibara Belt ore was investigated. The ore sample contained $0.01 \% \mathrm{Nb}$ and $0.04 \%$ Ta and a high Si content of $32.42 \%$. $\mathrm{Nb}$ and $\mathrm{Ta}$ appeared in the sample in several mineral phases such as Pyrochlore, Tapiolite and Ilmenorutile and major gangue minerals were quarts and mica. The flotation results deduced that the liberation of $\mathrm{Nb}$ and Ta minerals would require fine grinding at a risk of producing excessive fines which would affect the flotation process. Flotation of $\mathrm{Nb}$ and Ta minerals is best performed at high collector dosage. However, this might lead to high cost of the whole process. Based on these findings and previous discussions, AM810 hydroxamic acid has potential in the flotation of $\mathrm{Nb}$-Ta minerals.

\section{Acknowledgements}

Acknowledgements go out to the Department of Higher Education and Training of South Africa and the University of Johannesburg for funding this project.

\section{References}

[1] C.E. Gibson, S. Kelebek, M. Aghamirian, "Niobium oxide mineral flotation: A review of relevant literature and the current state of industrial operations," International Journal of Mineral Processing, vol. 137, pp 82 - 97, 2015.

[2] M. Wa Kalenga, D. Mutombo, W. Nheta. "Effect of Time on Formation of Phases in the Slag during Tin Production". Proceedings of Materials Science and Technology (MS\&T), Columbus OH, USA, October 14 - 18, 2018.

[3] N. Berman, M. Couttenier, D. Rohner, M. Thoenig, "This mine is mine! How minerals fuel conflicts in Africa”. American Economic Review, vol 107, no 6, pp 1564 - 1610, 2017

[4] Y. Ghorbani, R. Fitzpatrick, M. Kinchington, G. Rollinson, P. Hegarty, "A Process Mineralogy Approach to Gravity Concentration of Tantalum Bearing Minerals". Minerals, vol. 7, no. 10, pp 194. 2017

[5] S.M. Bulatovic, "Flotation of niobium/tantalum ores" in Handbook of Flotation Reagents: Chemistry, Theory and Practice-Volume 2: Flotation of Gold, PGM and Oxide Minerals: Elsevier BV, 2010, pp. 111125.

[6] X. Ni, M. Parrent, M. Cao, L. Huang, A. Bouajila, Q. Liu, "Developing flotation reagents for niobium oxide recovery form carbonatite $\mathrm{Nb}$ ores," Mineral Eng., vol. 36, no. 38, pp 111 - 118, 2012.

[7] F. Li, H Zhong, G Zhao, S. Wang, G. Liu, "Flotation performances and adsorption mechanism of $\alpha$-hydroxyoctyl phosphinic acid to cassiterite," Applied Surface Science., vol. 353, pp 856 -864, 2015 